\title{
Honeybush Extracts (Cyclopia spp.) Rescue Mitochondrial Functions and Bioenergetics against Oxidative Injury
}

\author{
Anastasia Agapouda $\mathbb{D}^{1,2}$ Veronika Butterweck $\mathbb{D}^{3},{ }^{3}$ Matthias Hamburger $\mathbb{D}^{4},{ }^{4}$ \\ Dalene de Beer $\mathbb{D},{ }^{5,6}$ Elizabeth Joubert $\mathbb{D}^{5,}, 6$ and Anne Eckert $\mathbb{D}^{1,2}$ \\ ${ }^{1}$ University of Basel, Transfaculty Research Platform, Molecular and Cognitive Neuroscience, Neurobiology Lab for Brain Aging and \\ Mental Health, Basel, Switzerland \\ ${ }^{2}$ Psychiatric University Clinics, Basel, Switzerland \\ ${ }^{3}$ University of Applied Sciences and Arts Northwestern Switzerland (FHNW), School of Life Sciences, Institute of \\ Pharmaceutical Technology, Gründenstrasse 40, 4132 Muttenz, Switzerland \\ ${ }^{4}$ Division of Pharmaceutical Biology, Department of Pharmaceutical Sciences, University of Basel, Basel, Switzerland \\ ${ }^{5}$ Plant Bioactives Group, Post-Harvest and Agro-Processing Technologies, Agricultural Research Council (ARC) Infruitec-Nietvoorbij, \\ Private Bag X5026, Stellenbosch 7599, South Africa \\ ${ }^{6}$ Department of Food Science, Stellenbosch University, Private Bag X1, Matieland, Stellenbosch, South Africa
}

Correspondence should be addressed to Anne Eckert; anne.eckert@unibas.ch

Received 23 April 2020; Accepted 9 June 2020; Published 7 August 2020

Guest Editor: Francisco Jaime B. Mendonça Junior

Copyright (c) 2020 Anastasia Agapouda et al. This is an open access article distributed under the Creative Commons Attribution License, which permits unrestricted use, distribution, and reproduction in any medium, provided the original work is properly cited.

\begin{abstract}
Mitochondrial dysfunction plays a major role not only in the pathogenesis of many oxidative stress or age-related diseases such as neurodegenerative as well as mental disorders but also in normal aging. There is evidence that oxidative stress and mitochondrial dysfunction are the most upstream and common events in the pathomechanisms of neurodegeneration. Cyclopia species are endemic South African plants and some have a long tradition of use as herbal tea, known as honeybush tea. Extracts of the tea are gaining more scientific attention due to their phenolic composition. In the present study, we tested not only the in vitro mitochondria-enhancing properties of honeybush extracts under physiological conditions but also their ameliorative properties under oxidative stress situations. Hot water and ethanolic extracts of C. subternata, C. genistoides, and C. longifolia were investigated. Pretreatment of human neuroblastoma SH-SY5Y cells with honeybush extracts, at a concentration range of 0.1$1 \mathrm{ng} / \mathrm{ml}$, had a beneficial effect on bioenergetics as it increased ATP production, respiration, and mitochondrial membrane potential (MMP) after 24 hours under physiological conditions. The aqueous extracts of C. subternata and C. genistoides, in particular, showed a protective effect by rescuing the bioenergetic and mitochondrial deficits under oxidative stress conditions ( $400 \mu \mathrm{M} \mathrm{H} \mathrm{H}_{2} \mathrm{O}_{2}$ for 3 hours). These findings indicate that honeybush extracts could constitute candidates for the prevention of oxidative stress with an impact on aging processes and age-related neurodegenerative disorders potentially leading to the development of a condition-specific nutraceutical.
\end{abstract}

\section{Introduction}

Reactive oxygen species (ROS) are oxygen-containing chemical entities of great reactivity that have been in the spotlight as a common feature in many diseases. They are involved in neurodegenerative and cardiovascular diseases, cancer, atherosclerosis, diabetes, and also in normal aging [1-4]. ROS include mainly superoxide anion radical $\left(\mathrm{O}_{2}^{--}\right)$, hydrogen peroxide $\left(\mathrm{H}_{2} \mathrm{O}_{2}\right)$, and the hydroxyl radical $\left(\mathrm{OH}^{-}\right)$of which superoxide anion and hydrogen peroxide are found in the most abundance in cells [5]. Mitochondria are organelles which are responsible for the majority of adenosine triphosphate (ATP) production through oxidative phosphorylation (OXPHOS) taking place at their electron transport chain (ETC). Neurons are high-energy demanding cells and thus are highly dependent on mitochondria in order to survive 
and function. However, mitochondria are also the epicenter of ROS production and metabolism [2,6]. Despite an estimation of 31 existing ROS (mostly superoxide anion and $\mathrm{H}_{2} \mathrm{O}_{2}$ ) production sites in the entire cell versus 12 ROS emission sites in the mitochondria, the majority of cellular endogenous ROS are produced by mitochondria as by-products of OXPHOS [5, 7].

Exposure to oxygen is not only unavoidable but also vital and necessary for organism and cell survival and for energy production [5]. Mitochondrial ROS are mostly generated by complexes I and III of the ETC when leaking electrons that are provided by NADH or $\mathrm{FADH}_{2}$ react with oxygen. Interestingly, the two high-production sites releasing $\mathrm{O}_{2}{ }^{--}$and $\mathrm{H}_{2} \mathrm{O}_{2}$ directly into the intermembrane space are the enzyme sn-glycerol-3-phosphate dehydrogenase and complex III of the ETC [5]. As a result, the presence of ROS in the intermembrane space may cause depolarization of the membranes and hinder the free motion of electrons through complexes I-IV, thereby directly affecting the proton gradient and the mitochondrial membrane potential (MMP) and ultimately preventing the production of ATP [8].

As mitochondria are the main superoxide anion and hydrogen peroxide producers, they largely affect redox homeostasis [9]. For their protection, cells are equipped with antioxidant defense systems (superoxide dismutases, glutathione peroxidases, thioredoxin, catalase, and glutathione GSH) in order to fend off ROS [10-12]. The redox state of the cells is dynamic and depends on the production of ROS and the functionality of the antioxidant defense systems. At normal nonelevated concentrations, ROS act as signaling molecules and they participate in the regulation of senescence, cell death, and proliferation. When there is an overproduction of ROS, the antioxidant defense systems are overwhelmed and they are not able to diffuse them. Therefore, oxidative stress is the overaccumulation of ROS (mainly superoxide anion and $\mathrm{H}_{2} \mathrm{O}_{2}$ ) due to their overproduction or overburdened antioxidant defense systems $[1,5]$. ROS react with and damage many cellular and mitochondrial biomolecules. Of note, they cause lipid peroxidation and membrane damage, protein misfolding, as well as DNA damage [3]. Mitochondrial DNA (mtDNA) is located in the matrix of mitochondria and encodes for 13 proteins which are structural components of the ETC. MtDNA is in very close proximity to the ROS production sites and is therefore directly affected and mutated, leading to faulty ETC components which leads back to impaired OXPHOS and more production of ROS $[10,13]$. When the ROS levels surpass a certain threshold, then they become mitochondria-damaging and disease-causing agents [14]. Aging is characterized by an increase in ROS and a decrease in antioxidant defenses leading to mitochondrial damage and ultimately to cellular dysfunction, senescence, and apoptosis. Normal aging and neurodegenerative disorders have these characteristics in common although to a different extent. In neurodegeneration, the damaging effects are even more profound $[3,5,9,15]$.

Hydrogen peroxide, which is endogenously produced in mitochondria, is considered the ROS with the most impact on the fate of the cell. It can easily diffuse through mem- branes and has the greatest life span [9]. Therefore, hydrogen peroxide was used as an oxidative stressor in this study.

Cyclopia species, belonging to the Fabaceae family, are endemic to South Africa. Old records describe the traditional use of several species including C. subternata, C. genistoides, and C. longifolia as herbal teas [16]. At present, these Cyclopia species form the bulk of cultivated plant material supplementing plant material harvested in the wild and crucial to meet the growing demand of international markets. The main product is "fermented" (oxidised) honeybush tea, while the green (unoxidised) herbal tea is preferred for nutraceutical extract production due to a higher phenolic content and antioxidant capacity. The phenolic profile of honeybush varies qualitatively and quantitatively depending on the Cyclopia species. Major phenolic constituents belong to xanthone, benzophenone, flavanone, flavone, and dihydrochalcone subclasses [17]. Increased consumption and popularity of honeybush came along with increasing research interest in order to reveal new bioactivities and to examine its potential use as a nutraceutical and functional food $[16,18]$. Quite predictably due to their phenolic composition, honeybush extracts have been shown to possess antioxidant activities which are of great importance and interest in the research of oxidative stress-related diseases [19-22]. Considering on the one hand the evidence of its antioxidant capacity and on the other hand the need for mitochondria-targeting antioxidant substances for use in the prevention of oxidative damage or the amelioration of increased oxidative stress levels, we hypothesized that honeybush could possess some beneficial mitochondria-enhancing properties. For this reason, this study is aimed at examining the protective effects of honeybush extracts against $\mathrm{H}_{2} \mathrm{O}_{2}$-induced oxidative stress in SH-SY5Y neuronal cells with a focus on mitochondria. To our knowledge, this is the first study that evaluates the effects of honeybush extracts on mitochondrial function in a neuronal cell model.

\section{Materials and Methods}

2.1. Chemicals and Reagents. Dulbecco's modified Eagle medium (DMEM), phosphate-buffered saline (PBS), fetal calf serum (FCS), Hanks' balanced salt solution (HBSS), penicillin/streptomycin, pyruvate, dihydrorhodamine 123 (DHR), $2^{\prime}, 7^{\prime}$-dichlorodihydrofluorescein diacetate (DCF), dihydroethidium (DHE), tetramethylrhodamine methyl ester (TMRM), gelatin, and $\mathrm{H}_{2} \mathrm{O}_{2}$ were from Sigma-Aldrich (St. Louis, MO, USA). MitoSOX and GlutaMAX were from Gibco Invitrogen (Waltham, MA, USA), ATPlitelstep kit from PerkinElmer (Waltham, Massachusetts, USA), and XF Cell Mitostress kit from Seahorse Bioscience (North Billerica, MA, USA). Folin-Ciocalteau reagent was purchased from Merck (Darmstadt, Germany). Authentic reference standards (purity $>95 \%$ ) for identification and quantification of phenolic compounds were obtained from Sigma-Aldrich (hesperidin), Extrasynthese (Genay, France; mangiferin, eriocitrin), Chemos (Regenstauf, Germany; isomangiferin), and Phytolab (Vestenbergsreuth, Germany; vicenin-2, 3- $\beta$ D-glucopyranosyliriflophenone). Compounds from the Plant Bioactives Group library included 3- $\beta$-D- 
glucopyranosyl-4-O- $\beta$-D-glucopyranosyliriflophenone, 3- $\beta$ $\mathrm{D}$-glucopyranosylmaclurin and (2S)-5-O-[ $\alpha$-L-rhamnopyranosyl-( $1 \rightarrow 2)-\beta$-D-glucopyranosyl] naringenin isolated from C. genistoides, and scolymoside and $3^{\prime}, 5^{\prime}$-di- $\beta$-D-glucopyranosylphloretin isolated from $C$. subternata. HPLC gradient grade "far UV" acetonitrile was supplied by Merck.

2.2. Plant Material and Extract Preparation. Harvesting of aerial parts (shoots and leaves) occurred in March 2017. Cyclopia subternata was harvested on Elsenburg research farm $(-34.30267,19.13809)$, while C. longifolia and C. genistoides were harvested on Nietvoorbij research farm $(-33.90619,18.87031)$, both located in the Western Cape Province of South Africa. The fresh plant material was mechanically cut into small pieces $(<3 \mathrm{~mm})$ and dried at $40^{\circ} \mathrm{C}$ in a cross-flow, temperature-controlled drying tunnel to a moisture content $<7 \%$ as for green honeybush tea production. The dried plant material was coarsely milled using a rotary mill equipped with a $1 \mathrm{~mm}$ sieve (Retsch, $\mathrm{GmbH}$, Haan, Germany).

Hot water extracts were prepared from each batch of milled plant material by extracting $70 \mathrm{~g}$ plant material with $700 \mathrm{ml}$ deionised water at $93^{\circ} \mathrm{C}$ for $30 \mathrm{~min}$ followed by filtration and freeze drying of the filtrate as previously described [23]. Similarly, 40\% EtOH-water (v/v) extracts were prepared by extracting the milled plant material at $70^{\circ} \mathrm{C}$ for $30 \mathrm{~min}$. Ethanol was removed under vacuum using rotary evaporation, and the remaining aqueous layer was freeze-dried. Prior to extraction using $70 \% \mathrm{EtOH}-$ water $(\mathrm{v} / \mathrm{v})$, the plant material was subjected to exhaustive Soxhlet extraction with dichloromethane to remove chlorophyll. The defatted plant material was air-dried and further treated as for the $40 \% \mathrm{EtOH}$-water (v/v) extracts. The freeze-dried extracts $(>15 \mathrm{~g} /$ extract $)$ were coded, aliquoted into glass vials (for testing and retention samples), sealed, and stored under desiccation in the dark.

\subsection{Quantification and Identification of Phenolic} Compounds. The major phenolic compounds in the extracts were quantified using the respective species-specific validated HPLC-DAD method for C. subternata [23], C. longifolia [24], and C. genistoides [25]. Samples were dissolved in water or $10 \%$ DMSO and filtered using $0.45 \mu \mathrm{m}$ pore size PVDF syringe filters (Merck) for C. subternata, while $0.22 \mu \mathrm{m}$ pore size filters were used for C. genistoides and C. longifolia. Ascorbic acid was added to prevent compound degradation during analysis (final concentration ca $9 \mathrm{mg} / \mathrm{ml}$ ). Peak areas at the appropriate wavelength together with external calibration curves were used for quantification (benzophenones, flavanones, and dihydrochalcones at $288 \mathrm{~nm}$; xanthones and flavones at $320 \mathrm{~nm}$ ). In cases where authentic reference standards were not available, quantification was in equivalents of a similar compound.

Total polyphenol content of extracts was determined using the Folin-Ciocalteau assay as adapted for microplate by Arthur et al. [26]. Values were expressed as g gallic acid equivalents per $100 \mathrm{~g}$ extract.

Extracts selected for further study after initial testing were also analyzed by LC-MS using a Waters Acquity ultra- performance liquid chromatography (UPLC) instrument coupled to a Synapt G2 quadrupole time-of-flight (Q-TOF) MS detector equipped with an electrospray ionization (ESI) source (Waters, Milford, USA). Mass calibration was performed using a sodium formate solution, and leucine enkephalin was used as the lockspray solution. Analysis was first performed in the $\mathrm{MS}^{\mathrm{E}}$ mode with negative ionization: scanning range, $150-1500 \mathrm{am}$; capillary voltage, $-2.5 \mathrm{kV}$; sampling cone voltage, $15.0 \mathrm{~V}$; source temperature, $120^{\circ} \mathrm{C}$; desolvation temperature, $275^{\circ} \mathrm{C}$; cone gas flow $\left(\mathrm{N}_{2}\right), 650 \mathrm{l} / \mathrm{h}$; desolvation gas flow $\left(\mathrm{N}_{2}\right), 50 \mathrm{l} / \mathrm{h}$. For the MS/MS experiments, a collision energy of $30.0 \mathrm{~V}$ was used. Peaks were identified by comparing UV-Vis spectra, relative retention time, MS characteristics (molecular formula predicted by accurate mass), and MS/MS fragmentation spectra with those of authentic standards or literature data.

2.4. Cell Culture. The human neuroblastoma SH-SY5Y cell line was selected as our cellular model in this study as it is a well-established and widely used neuronal model in biochemical studies in general. The cell line behaves as human neuronal network in a dish and has been largely used in research as it expresses neuronal receptors. The SH-SY5Y cells were kept and grown at $37^{\circ} \mathrm{C}$ in a humidified incubator chamber under an atmosphere of $7.5 \% \mathrm{CO}_{2}$ in DMEM supplemented with $10 \%(\mathrm{v} / \mathrm{v})$ heat-inactivated FCS, $2 \mathrm{mM}$ GlutaMAX, and $1 \%(\mathrm{v} / \mathrm{v})$ penicillin/streptomycin. Cells were passaged 1-2 times per week, and the cells used for the experiments did not exceed passage 20 . The cells were plated when they reached $80-90 \%$ confluence.

2.5. Treatment of Cells. Evaluation of ATP production was conducted on SH-SY5Y neuroblastoma cells to determine the potential toxic concentration range of the nine honeybush extracts. Two screenings were performed. Initially, aqueous, $70 \%$ ethanolic and $40 \%$ ethanolic extracts of the species C. subternata, C. genistoides, and C. longifolia were screened at a very broad concentration range of $0.1 \mathrm{ng} / \mathrm{ml}$ to $1 \mathrm{mg} / \mathrm{ml}$ (data not shown). Of note, all dry extracts were dissolved in DMSO for our experiments (final concentration of DMSO $<0.005 \%$, no effect of the vehicle solution alone compared to the untreated condition). The first screening revealed that the extracts were not toxic for the neuroblastoma cells up to a concentration of $10 \mu \mathrm{g} / \mathrm{ml}$. According to the results of the first screening, the concentration range was reduced down to that of $0.1 \mathrm{ng} / \mathrm{ml}$ to $1 \mu \mathrm{g} / \mathrm{ml}$ and the number of extracts was reduced from nine down to four (according to the capacity of the extracts in increasing the ATP levels of the cells) and a second screening cycle was performed. The screening was conducted by using an ATP detection assay (ATPlite 1step kit was from PerkinElmer). For the experiments, cells were plated and treated 1 day after plating for $24 \mathrm{~h}$ either with DMEM (untreated cells-control condition) or with a final concentration of $0.1 \mathrm{ng} / \mathrm{ml}$ to $1 \mu \mathrm{g} / \mathrm{ml}$ of the extracts.

Because vehicle treatment was without any effect in our assays, we evaluated the effects of the honeybush extract concentrations in comparison to the untreated control condition in the following experiments. Cellular sensitivity of SH-SY5Y 
cells was confirmed by using the positive control estradiol as previously described in Grimm et al. 2014 [27].

Hydrogen peroxide $\left(\mathrm{H}_{2} \mathrm{O}_{2}\right)$ which belongs to the reactive oxygen species produced by mitochondria was used as a stressor at the concentration $400 \mu \mathrm{M}$ which was able to decrease mitochondrial and cellular functions. The $\mathrm{H}_{2} \mathrm{O}_{2}$ concentration was selected based on screening experiments conducted on SH-SY5Y cells. For the stress experiments, cells were firstly pretreated for $24 \mathrm{~h}$ with the honeybush extracts and then treated for $3 \mathrm{~h}$ with $400 \mu \mathrm{M} \mathrm{H}_{2} \mathrm{O}_{2}$. Each assay was conducted and repeated at least in triplicate.

2.6. ATP Levels. Total ATP content was determined using a bioluminescence assay (ATPlite 1step) according to the instructions of the manufacturer and as previously described [28-30]. Cells were plated in 6 replicates into white 96-well cell culture plates at a density of $1 \times 10^{4}$ cells/well. The ATP was extracted from the cells upon lysis and it was transformed into light. The method measures the formation of light from ATP and luciferin catalyzed by the enzyme luciferase. The emitted light was linearly correlated to the ATP concentration and was measured using the multimode plate reader Cytation 3 (BioTek instruments, Winooski, Vermont, United States).

2.7. Determination of Mitochondrial Membrane Potential $(M M P)$. The MMP was measured using the fluorescent dye TMRM, since its transmembrane distribution depends on the MMP. As previously described [31, 32], the cells were plated in 6 replicates into black 96 -well cell culture plates at a density of $1 \times 10^{4}$ cells/well and were incubated with the dye at a concentration of $0.4 \mu \mathrm{M}$ for $20 \mathrm{~min}$. After washing three times with HBSS, fluorescence was measured at $548 \mathrm{~nm}$ (excitation)/574 nm (emission), using a Cytation 3 multimode plate reader (BioTek instruments).

2.8. Mitochondrial Respiration. Mitochondrial respiration and cellular glycolysis were measured using the Seahorse Bioscience XF24 analyser as described before [28, 29, 33]. Briefly, XF24 cell culture microplates were coated with $0.1 \%$ gelatin and cells were plated at a density of $2.5 \times 10^{4}$ cells/well in treatment medium $(100 \mu \mathrm{l})$ containing $1 \mathrm{~g} / \mathrm{l}$ glucose, $4 \mathrm{mM}$ pyruvate, and $10 \%$ FCS. After treatment with honeybush extracts for $24 \mathrm{~h}$, the cells were washed once with PBS and then $500 \mu \mathrm{l}$ of assay medium (DMEM containing $1 \mathrm{~g} / \mathrm{l}$ of glucose and $4 \mathrm{mM}$ of pyruvate) was added to each well. The oxygen consumption rate (OCR) and extracellular acidification rate (ECAR) were measured concurrently under basal respiration. The data were extracted from the Seahorse XF24 software, and bioenergetic parameters (basal respiration, ATP production, maximal respiration, spare respiratory capacity, and glycolytic reserve) were calculated according to the guidelines of the manufacturer.

2.9. Determination of ROS Levels. Mitochondrial and cytosolic ROS levels and the specific levels of mitochondrial $\mathrm{O}_{2}{ }^{--}$superoxide anion radicals and the total levels of $\mathrm{O}_{2}{ }^{--}$ superoxide anion radicals levels were assessed using the fluorescent dyes dihydrorhodamine 123 (DHR), $2^{\prime}, 7^{\prime}$-dichlorodihydrofluorescein diacetate (DCF), the Red Mitochondrial
Superoxide Indicator (MitoSOX), and dihydroethidium (DHE), respectively, as described before [30, 34]. SH-SY5Y cells were plated in 6 replicates into black 96 -well cell culture plates at a density of $1 \times 10^{4}$ cells/well. After treatment with honeybush extracts alone or after pretreatment with honeybush extracts, followed by treatment with $\mathrm{H}_{2} \mathrm{O}_{2}$, cells were treated with $10 \mu \mathrm{M}$ of one of the dyes: DCF, DHR, or DHE for $20 \mathrm{~min}$ or $5 \mu \mathrm{M}$ of MitoSOX for $90 \mathrm{~min}$ at room temperature in the dark on an orbital shaker. After washing the cells three times with HBSS, the formation of green fluorescent products triggered by DCF and DHR, respectively, was detected at $485 \mathrm{~nm}$ (excitation)/535 nm (emission). MitoSOX triggers the formation of red fluorescent products which were detected at $531 \mathrm{~nm}$ (excitation)/595 nm (emission). DHE, which is permeable to cells, is used as a total $\mathrm{O}_{2}{ }^{--}$superoxide anion detector as it is oxidised to the impermeable red fluorescent product ethidium, detected at $531 \mathrm{~nm}$ (excitation)/595 nm (emission). The intensity of fluorescence was proportional to mitochondrial ROS, cytosolic ROS, and $\mathrm{O}_{2}{ }^{--}$levels (total and mitochondrial). The fluorescence was measured using the Cytation 3 multimode plate reader.

2.10. Statistical Analysis. Data are given as the mean \pm SEM. Statistical analyses were performed using GraphPad Prism software (version 5.02 for Windows, San Diego, California, USA). For statistical comparisons of more than two groups, one-way ANOVA was used, followed by a Dunnett's multiple comparison tests versus the control for physiological conditions and versus $\mathrm{H}_{2} \mathrm{O}_{2}$ for stress conditions. $P<0.05$ was considered statistically significant.

\section{Results}

Two cycles of screenings were conducted with regard to the ability of each extract in increasing the ATP production of SH-SY5Y cells. The nine Cyclopia extracts produced by extraction of C. subternata, C. genistoides, and C. longifolia with hot water and two ethanol-water mixtures were screened (data not shown), and the four most promising extracts in terms of increased ATP production were selected for all subsequent experiments: the water extracts of all three Cyclopia species and the $70 \%$ ethanolic extract of C. genistoides. Table 1 gives the content of the major phenolic compounds present in the selected extracts. Qualitative and quantitative differences in the phenolic profile are evident, notably the absence or presence of only trace levels of dihydrochalcones in C. longifolia and C. genistoides but substantial xanthone levels compared to C. subternata. Mangiferin followed by isomangiferin was the predominant compound in the C. longifolia and C. genistoides extracts. Scolymoside, a flavone rutinoside, followed by 3- $\beta$-D-glucopyranosyl-4$O$ - $\beta$-D-glucopyranosyliriflophenone, a benzophenone, was the main phenolic compound in C. subternata water extract. Scolymoside was not detected in the two C. genistoides extracts, but these extracts had substantially higher levels of the flavone di-glucoside, vicenin-2, compared to the C. subternata and C. longifolia extracts. Overall, the total phenolic content, based on the sum of individual phenolic compound content, was highest in the $70 \% \mathrm{EtOH}$-water extract of $C$. 
TABLE 1: Phenolic composition (g/100 g extract) of aqueous extracts of Cyclopia subternata, Cyclopia longifolia, and Cyclopia genistoides and a $70 \%$ ethanolic extract of C. genistoides.

\begin{tabular}{|c|c|c|c|c|}
\hline \multirow{2}{*}{ Compounds } & \multirow{2}{*}{$\begin{array}{c}\text { C. subternata } \\
\text { Water }\end{array}$} & \multirow{2}{*}{$\begin{array}{l}\text { C. longifolia } \\
\text { Water }\end{array}$} & \multicolumn{2}{|c|}{ C. genistoides } \\
\hline & & & Water & $70 \% \mathrm{EtOH}$ \\
\hline \multicolumn{5}{|l|}{ Benzophenones } \\
\hline Maclurin-di-O,C-hexoside (MDH) ${ }^{\mathrm{a}}$ & nd & nd & 0.079 & 0.061 \\
\hline 3- $\beta$-D-Glucopyranosyl-4-O- $\beta$-D-glucopyranosyliriflophenone (IDG) & 1.67 & 0.700 & 1.78 & 1.41 \\
\hline 3- $\beta$-D-Glucopyranosylmaclurin (MMG) & nd & nd & 0.400 & 0.373 \\
\hline 3- $\beta$-D-Glucopyranosyliriflophenone (IMG) & 0.536 & 0.076 & 1.52 & 1.12 \\
\hline Total benzophenones & 2.21 & 0.776 & 3.77 & 2.97 \\
\hline \multicolumn{5}{|l|}{ Xanthones } \\
\hline Tetrahydroxyxanthone-di-O,C-hexoside A (THXA) ${ }^{\mathrm{b}}$ & $\mathrm{nq}$ & 0.168 & $\mathrm{nq}$ & nq \\
\hline Tetrahydroxyxanthone-di-O,C-hexoside B (THXB) ${ }^{\mathrm{b}}$ & $\mathrm{nq}$ & 0.133 & $\mathrm{nq}$ & $\mathrm{nq}$ \\
\hline Mangiferin & 1.16 & 6.38 & 6.86 & 9.66 \\
\hline Isomangiferin & 0.458 & 1.84 & 1.97 & 2.36 \\
\hline Total xanthones & 1.62 & 8.53 & 8.83 & 12.0 \\
\hline \multicolumn{5}{|l|}{ Flavones } \\
\hline Vicenin-2 & 0.182 & 0.192 & 0.498 & 0.524 \\
\hline Scolymoside & 1.84 & 0.497 & $\mathrm{nq}$ & $\mathrm{nq}$ \\
\hline Total flavones & 2.02 & 0.690 & 0.498 & 0.524 \\
\hline \multicolumn{5}{|l|}{ Dihydrochalcones } \\
\hline 3-Hydroxyphloretin-di-C-hexoside (HPDH) ${ }^{c}$ & 0.458 & $\mathrm{nq}$ & $\mathrm{nq}$ & nq \\
\hline $3^{\prime}, 5^{\prime}$-Di- $\beta$-D-glucopyranosylphloretin (PDG) & 1.22 & nq & $\mathrm{nq}$ & $\mathrm{nq}$ \\
\hline Total dihydrochalcones & 1.67 & 0.000 & 0.000 & 0.000 \\
\hline \multicolumn{5}{|l|}{ Flavanones } \\
\hline Eriodictyol-O-hexoside-O-deoxyhexoside (EHD) ${ }^{\mathrm{d}}$ & nd & 0.186 & 0.297 & 0.195 \\
\hline$(2 R)-5-O$ - $\left[\alpha\right.$-L-Rhamnopyranosyl- $(1 \rightarrow 2)-\beta$-D-glucopyranosyl] naringenin $(2 \mathrm{RNAR})^{\mathrm{e}}$ & nd & 0.028 & 0.146 & 0.051 \\
\hline (2S)-5-O-[ $\alpha$-L-Rhamnopyranosyl-( $1 \rightarrow 2)$ - $\beta$-D-glucopyranosyl] naringenin (2SNAR) & nd & 0.087 & 0.397 & 0.444 \\
\hline Eriocitrin & 0.536 & 0.310 & $\mathrm{nq}$ & $\mathrm{nq}$ \\
\hline Hesperidin & 1.43 & 0.839 & 0.988 & 1.73 \\
\hline Total flavanones & 1.96 & 1.45 & 1.83 & 2.42 \\
\hline Total quantified phenolics & 9.48 & 11.5 & 14.9 & 17.9 \\
\hline Total polyphenols (Folin-Ciocalteau) ${ }^{\mathrm{f}}$ & 25.5 & 23.7 & 25.3 & 27.8 \\
\hline
\end{tabular}

${ }^{a}$ Expressed as MMG equivalents. ${ }^{b}$ Expressed as mangiferin equivalents. ${ }^{c}$ Expressed as PDG equivalents. ${ }^{\mathrm{d}}$ Expressed as eriocitrin equivalents. ${ }^{\mathrm{e}}$ Expressed as 2SNAR equivalents. ${ }^{\mathrm{f}}$ Expressed as g gallic acid equivalents/100 g extract. nd: not detected using LC-MS; nq: present in extract, but not quantified due to coelution of very low content.

genistoides and lowest in the water extract of C. subternata. The total polyphenol content determined using the FolinCiocalteau assay was highest in the $70 \% \mathrm{EtOH}$-water extract of C. genistoides and lowest in the water extract of C. longifolia with similar values for the water extracts of $C$. subternata and C. genistoides (Table 1).

3.1. Honeybush Extracts Increase ATP Production under Physiological Conditions and under $\mathrm{H}_{2} \mathrm{O}_{2}$-Induced Stress. ATP is the end product not only of mainly oxidative phosphorylation but also of glycolysis and is thus an indicator of mitochondrial and cellular viability and proper functioning. Therefore, we assessed the effect of the honeybush extracts on the ATP production of neuroblastoma cells. The concentration range of $0.1-1000 \mathrm{ng} / \mathrm{ml}$ for each extract was first tested under physiological conditions. The results indicated that the lower concentrations $(0.1-1 \mathrm{ng} / \mathrm{ml})$, but not the higher ones $(50 \mathrm{ng} / \mathrm{ml}-100 \mathrm{mg} / \mathrm{ml}$, data not shown), of the water extracts of the three Cyclopia species and of the $70 \%$ ethanolic extract of C. genistoides significantly increased ATP production up to $4 \%$ after treatment for $24 \mathrm{~h}$ under physiological conditions (Figures $1(\mathrm{a})-1(\mathrm{~d})$ ).

Regarding ATP levels under oxidative stress, $\mathrm{H}_{2} \mathrm{O}_{2}$ at $400 \mu \mathrm{M}$ caused a $39.1 \%$ decrease in ATP production. According to the experimental design under physiological conditions, we tested the same broad concentration range for each extract under oxidative stress (data not shown). Again, the concentrations 0.1 and $1 \mathrm{ng} / \mathrm{ml}$ significantly protected against oxidative stress. Therefore, these concentrations were used in the following oxidative stress experiments. The harmful effect of $\mathrm{H}_{2} \mathrm{O}_{2}$ was partially but significantly ameliorated by all the extracts up to $13.5 \%$ (Figure 2 ). 


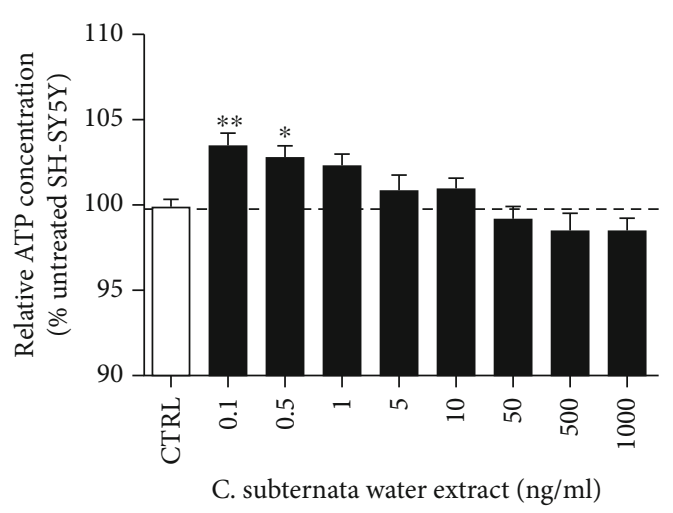

(a)

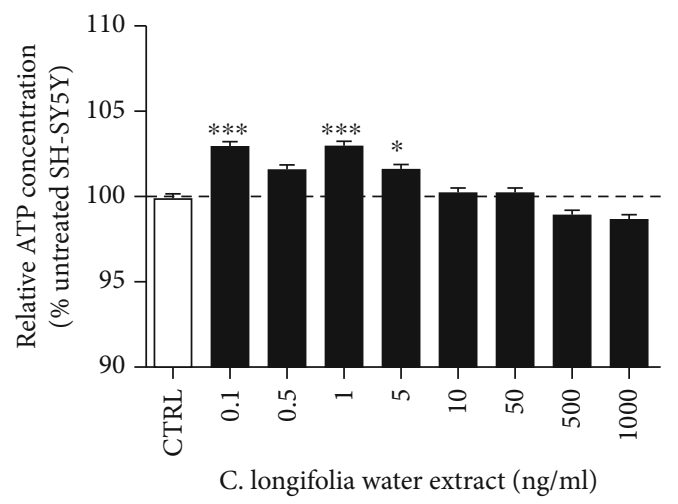

(c)

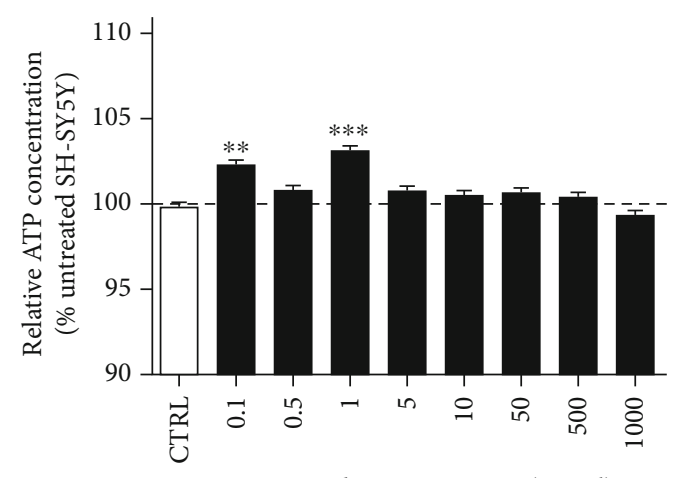

C. genistoides water extract $(\mathrm{ng} / \mathrm{ml})$

(b)

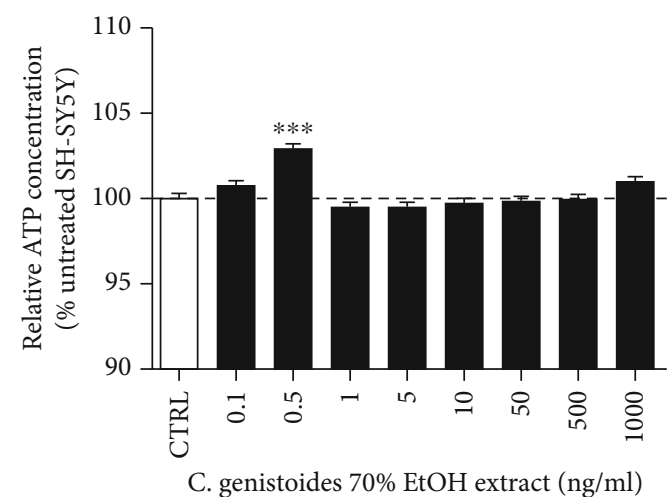

(d)

Figure 1: (a-d) The water extracts of Cyclopia subternata, C. genistoides, and C. longifolia, and the $70 \%$ ethanolic extract of C. genistoides significantly increased the ATP levels up to $4 \%$. The cells were treated for $24 \mathrm{~h}$ with the extracts. Values represent as the mean \pm SEM of three independent experiments and were normalized on the untreated (CTRL) group (=100\%). One-way ANOVA and post hoc Dunnett's multiple comparison test versus CTRL cells. ${ }^{*} P<0.05 ;{ }^{* *} P<0.01 ;{ }^{* * *} P<0.001$.

\subsection{Honeybush Extracts Increase Mitochondrial Respiration} under Physiological Conditions and under $\mathrm{H}_{2} \mathrm{O}_{2}$-Induced Stress. Mitochondria consume oxygen to perform respiration and oxidative phosphorylation. Thus, for an assessment of mitochondrial respiration, the oxygen consumption rate of the cells was measured live under basal conditions. The results indicated that the water extracts of C. subternata and C. genistoides and the $70 \%$ ethanolic extract of C. genistoides increased the respiration under physiological conditions at baseline. However, upon closer analysis of data, it was found that only the water extracts of C. subternata and C. genistoides at $1 \mathrm{ng} / \mathrm{ml}$ significantly increased the respiration by $33.2 \%$ and $40.7 \%$, respectively (Figure $3(\mathrm{a})$ ). The extracts that significantly increased the other pathway leading to the production of ATP, glycolysis, were C. genistoides ( $1 \mathrm{ng} / \mathrm{ml}$ ) and C. longifolia (at 0.1 and $1 \mathrm{ng} / \mathrm{ml}$ ). This increase was up to $51.7 \%$ (Figure 3(b)). Upon correlation of the respiration with the glycolysis, an "energy map" was obtained (Figure 3(c)) which allows a visual representation of where each individual extract acted. Thus, C. subternata and C. genistoides increased the oxygen consumption rate of the cells (respiration), while C. longifolia increased the glycolysis.

$\mathrm{H}_{2} \mathrm{O}_{2}$ caused a significant decrease of $41.7 \%$ in respiration (Figure 4(a), red bar). All extracts increased the oxygen consumption rate, bringing it closer to the levels of the untreated cells. However, only the water extract of C. subternata was able to significantly enhance respiration at baseline (increase of 25.9\%) (Figure 4(a)). Regarding glycolysis, $\mathrm{H}_{2} \mathrm{O}_{2}$ caused a significant decrease of $38.9 \%$ which was completely rescued by the water extract of C. genistoides $(1 \mathrm{ng} / \mathrm{ml})$ (Figure 4(b)). The "energy map" confirmed that the most effective extract in rescuing the respiration under $\mathrm{H}_{2} \mathrm{O}_{2}$ stress was the aqueous extract of C. subternata (Figure 4(c)).

3.3. Honeybush Extracts Increase Mitochondrial Membrane Potential (MMP) under Physiological Conditions and under $\mathrm{H}_{2} \mathrm{O}_{2}$-Induced Stress. The aqueous extracts of $C$. genistoides $(1 \mathrm{ng} / \mathrm{ml})$ and C. longifolia $(0.1$ and $1 \mathrm{ng} / \mathrm{ml})$ significantly increased MMP up to $24 \%$ under physiological conditions after a treatment of $24 \mathrm{~h}$ (Figure 5(a)).

$\mathrm{H}_{2} \mathrm{O}_{2}$ at $400 \mu \mathrm{M}$ caused a significant reduction of $55.1 \%$ in MMP which was increased by up to $67.9 \%$ by the extracts. In this case, all extracts completely rescued the MMP (Figure 5(b)).

Overall, all extracts acted on the mitochondrial membrane potential by increasing it both under physiological condition and under $\mathrm{H}_{2} \mathrm{O}_{2}$-induced oxidative stress.

3.4. Honeybush Extracts Decrease Different Types of ROS under $\mathrm{H}_{2} \mathrm{O}_{2}$-Induced Stress. $\mathrm{H}_{2} \mathrm{O}_{2}$ at $400 \mu \mathrm{M}$ caused an 


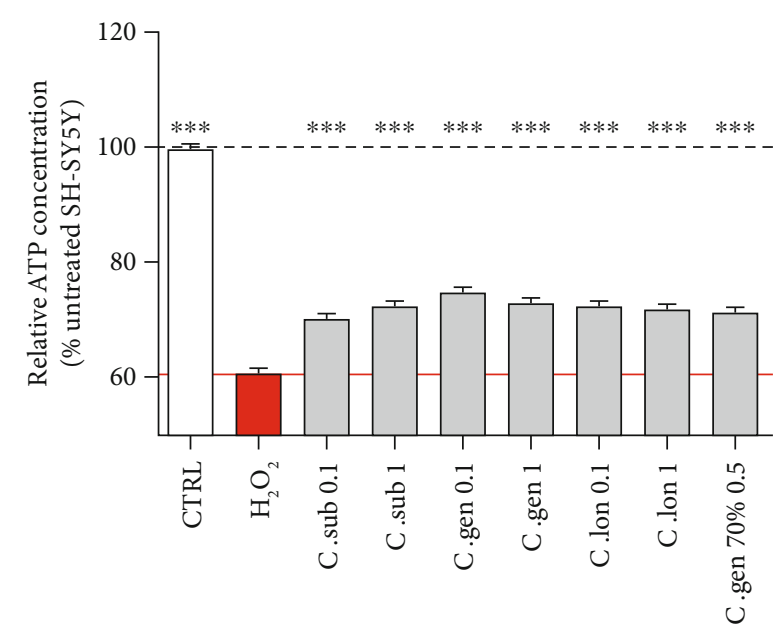

Figure 2: $\mathrm{H}_{2} \mathrm{O}_{2}$ treatment at $400 \mu \mathrm{M}$ for $3 \mathrm{~h}$ caused a $39.1 \%$ decrease in ATP production which was significantly increased up to $13.5 \%$ by a $24 \mathrm{~h}$ pretreatment with each of the extracts. The red bar represents the $\mathrm{H}_{2} \mathrm{O}_{2}$-treated cells, and the grey bars represent cells that were pretreated for $24 \mathrm{~h}$ with the indicated honeybush extract and then treated for $3 \mathrm{~h}$ with $\mathrm{H}_{2} \mathrm{O}_{2}$. Values represent as the mean \pm SEM of three independent experiments and were normalized on the untreated group $(=100 \%)$. One-way ANOVA and post hoc Dunnett's multiple comparison test versus $\mathrm{H}_{2} \mathrm{O}_{2}$ treated cells. ${ }^{*} P<0.05 ;{ }^{* *} P<0.01 ;{ }^{* * *} P<0.001$.

increase of $29.5 \%$ in mitochondrial ROS which was detected using the dye DHR (dihydrorhodamine 123). This increase was significantly ameliorated up to $23.1 \%$ by C. subternata water extract. C. genistoides also brought the ROS levels down but not significantly (Figure 6(a)).

Cytosolic ROS were detected using the dye DCF $\left(2^{\prime}, 7^{\prime}\right.$ -dichlorodihydrofluorescein diacetate). $\mathrm{H}_{2} \mathrm{O}_{2}$ at $400 \mu \mathrm{M}$ caused an elevation of $31.2 \%$. All extracts lowered cytosolic ROS levels, but the water extract of C. subternata at $1 \mathrm{ng} / \mathrm{ml}$ (28.9\% reduction of cytosolic ROS) and the $70 \%$ ethanolic extract of C. genistoides at $0.5 \mathrm{ng} / \mathrm{ml}(26.2 \%$ reduction of cytosolic ROS) were the most effective (Figure 6(b)).

$\mathrm{H}_{2} \mathrm{O}_{2}$ at $400 \mu \mathrm{M}$ increased the mitochondrial superoxide anion levels by $43 \%$. All extracts, except the ethanolic extract of $C$. genistoides, significantly lowered the mitochondrial superoxide anion levels. However, the water extracts of $C$. subternata, C. genistoides, and C. longifolia at a concentration of $1 \mathrm{ng} / \mathrm{ml}$ completely neutralized the mitochondrial superoxide anion levels (reduction of $42 \%, 42.6 \%$, and $42.6 \%$, respectively) (Figure 6(c)).

The total superoxide anion levels were elevated by $67.9 \%$ in the $\mathrm{H}_{2} \mathrm{O}_{2}$-treated cells. All four extracts ameliorated this increase, but only the water extracts of C. subternata and $C$. longifolia at $1 \mathrm{ng} / \mathrm{ml}$ and the ethanolic extract of $C$. genistoides at $0.5 \mathrm{ng} / \mathrm{ml}$ significantly reduced the superoxide anion levels by $48.8 \%, 50.9 \%$, and 50.3\%, respectively (Figure 6(d)).

\section{Discussion}

In this study, we hypothesized that honeybush extracts might exert a beneficial effect on mitochondria of neuronal cells under physiological conditions as well as under oxidative stress due to their phenolic compound content. Neurons have high energy demands and are thus particularly dependent on functional mitochondria. For this reason, we assessed the effects of four different honeybush extracts in a well-characterized neuronal model, the neuroblastoma $\mathrm{SH}$ SY5Y cells. The four extracts were the hot water extracts of C. subternata, C. genistoides, and C. longifolia as well as the $70 \%$ ethanolic extract of C. genistoides. These extracts were selected after screening the water, $40 \%$ ethanolic and $70 \%$ ethanolic extracts of these Cyclopia species. Hydrogen peroxide $\left(\mathrm{H}_{2} \mathrm{O}_{2}\right)$ was used as an oxidative stressor as it is one of the most abundant and reactive endogenous ROS.

The beneficial effect of honeybush extracts on mitochondrial functions under physiological conditions and a protective effect under oxidative stress could be demonstrated. The four extracts showed different beneficial properties in different mitochondrial and cellular sites. ATP is the energy that is required for the survival and functionality of cells and especially of neurons which have high energy demands. At the lowest concentrations $(0.1-1 \mathrm{ng} / \mathrm{ml})$, all extracts improved the production of ATP under physiological conditions. This increase amounted up to $4 \%$ (Figure 1). Also, all extracts were able to significantly increase the ATP levels under $\mathrm{H}_{2} \mathrm{O}_{2}$-induced oxidative stress. This improvement was not a complete rescue but a partial increase of up to $13.5 \%$ (Figure 2).

Mitochondrial respiration is an intrinsic function of mitochondria and is essential for the survival of the cells as it results in the production of the majority of ATP. Respiration is taking place at the ETC which is located on the inner mitochondrial membrane (IMM). Glycolysis is the secondary pathway leading to production of ATP. The aqueous extracts of C. subternata and C. genistoides (both at $1 \mathrm{ng} / \mathrm{ml}$ ) significantly increased the basal respiration of the mitochondria by up to $40.7 \%$, while those of C. genistoides and C. longifolia significantly increased glycolysis up to $51.7 \%$ under physiological conditions (Figure 3). However, only C. subternata aqueous extract $(1 \mathrm{ng} / \mathrm{ml})$ could significantly rescue the impaired respiration and only $C$. genistoides aqueous extract ( $1 \mathrm{ng} / \mathrm{ml}$ ) could rescue the impaired glycolysis caused by $\mathrm{H}_{2} \mathrm{O}_{2}$ (Figure 4). The aqueous extracts of C. subternata and C. genistoides specifically acted on respiration. In addition, the $C$. subternata aqueous extract enhanced respiration under oxidative stress. This could be explained by the fact that this extract was the only one that neutralized all four types of tested ROS and particularly the mitochondrial ROS and the mitochondrial superoxide anion which directly affect OXPHOS and respiration (Figure 6). This could be the reason why it was also the only extract to act on respiration under stress.

The aqueous extracts of C. genistoides and C. longifolia increased the MMP under physiological conditions, while all four extracts completely rescued the MMP under oxidative stress (Figure 5), in addition to partly ameliorating ATP production (Figure 2). During OXPHOS at the ETC of mitochondria, electrons provided by $\mathrm{NADH}$ and $\mathrm{FADH}_{2}$ are transferred through complexes I-IV. This motion of electrons drives the complexes I, III, and IV to pump protons into the intermembrane space where they are finally used 


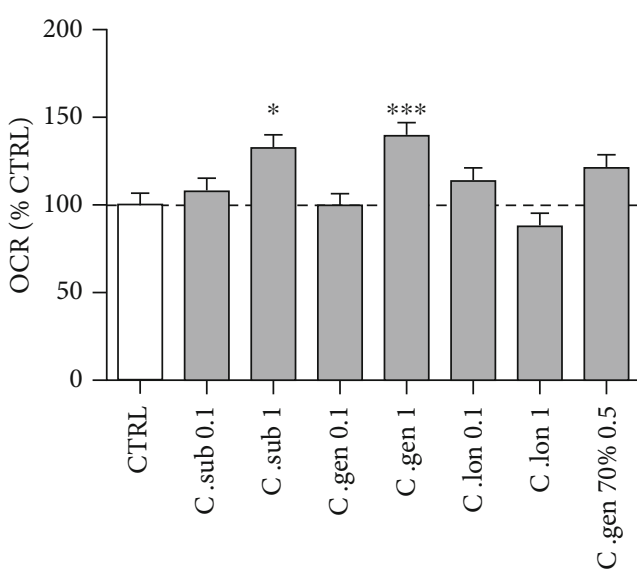

Honeybush extracts (ng/ml)

(a)

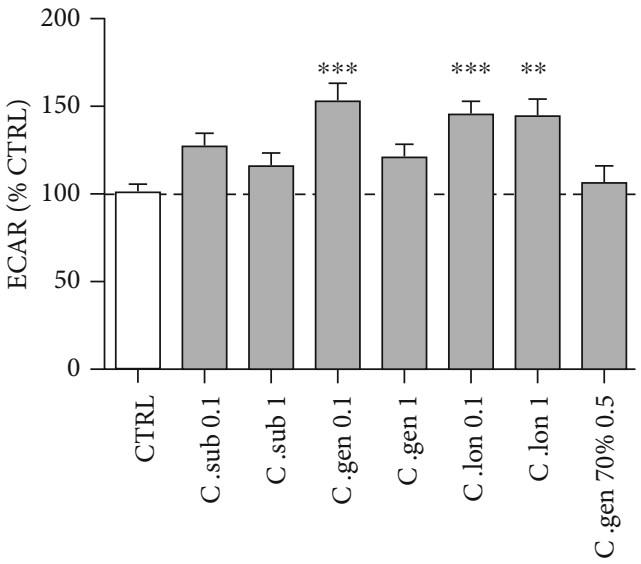

Honeybush extracts $(\mathrm{ng} / \mathrm{ml})$

(b)

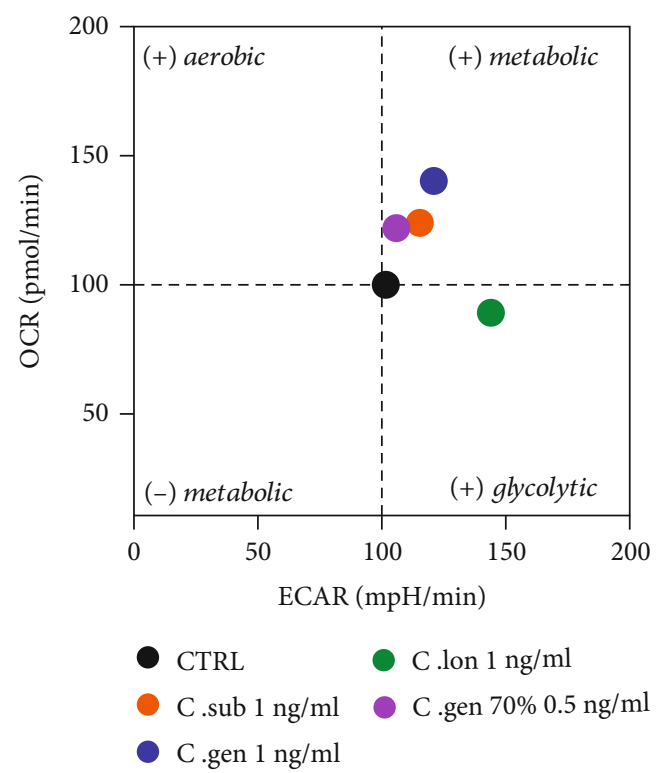

(c)

FIGURE 3: Respiration under physiological condition. (a) $24 \mathrm{~h}$ pretreatment with the water extracts of C. subternata and C. genistoides (both at $1 \mathrm{ng} / \mathrm{ml}$ ) significantly increased the oxygen consumption rate of the cells and therefore the respiration. (b) The water extracts of $C$. genistoides $(0.1 \mathrm{ng} / \mathrm{ml})$ and C. longifolia $(0.1$ and $1 \mathrm{ng} / \mathrm{ml})$ significantly increased the glycolysis in the SH-SY5Y cells. (c) Energy map created after correlation of the OCR (respiration- $y$-axis) with the ECAR (glycolysis- $x$-axis). The aqueous extracts of C. subternata and C. genistoides acted on respiration (displayed as + metabolic in the figure), while the water extract of $C$. longifolia increased the glycolytic activity. Values represent as the mean \pm SEM of three independent experiments and were normalized on the comparison test versus $\mathrm{H}_{2} \mathrm{O}_{2}$-treated cells. ${ }^{*} P<0.05 ;{ }^{* *} P<0.01 ;{ }^{* * *} P<0.001$.

by ATP synthase (complex V) to produce ATP via the phosphorylation of ADP. MMP is an indicator for polarized mitochondrial membranes and therefore an indicator that the pumping of protons in the intermembrane space is not hindered so that they can drive the ATP production by complex $\mathrm{V}[35,36]$. Amelioration of ATP production under oxidative stress by the extracts could be as a result of their capacity to completely rescue the MMP under oxidative stress and supports this interdependence of MMP and ATP production.

In terms of ROS (Figure 6), pretreatment with the aqueous extract of C. subternata (mostly at $1 \mathrm{ng} / \mathrm{ml}$ ) decreased the four types of tested ROS and it was the only extract of those tested to significantly reduce the mitochondrial ROS (detected with the dye DHR). The result that C. subternata extract acted both on mitochondrial superoxide anion levels (detected with the dye MitoSOX) and on all other mitochondrial ROS, such as $\mathrm{H}_{2} \mathrm{O}_{2}$ (detected with the dye DHR), could mean that it either additionally scavenges them or it enhances the activity of the antioxidant defenses that neutralize them (e.g., glutathione, catalase) [21]. The aqueous extract of C. longifolia lowered cytosolic ROS, total superoxide anion levels, and mitochondrial superoxide anion levels. The two C. genistoides extracts differed, i.e., its aqueous extract neutralized cytosolic ROS and mitochondrial superoxide anion, while its $70 \%$ ethanolic extract decreased cytosolic ROS and total superoxide anion levels but had no 


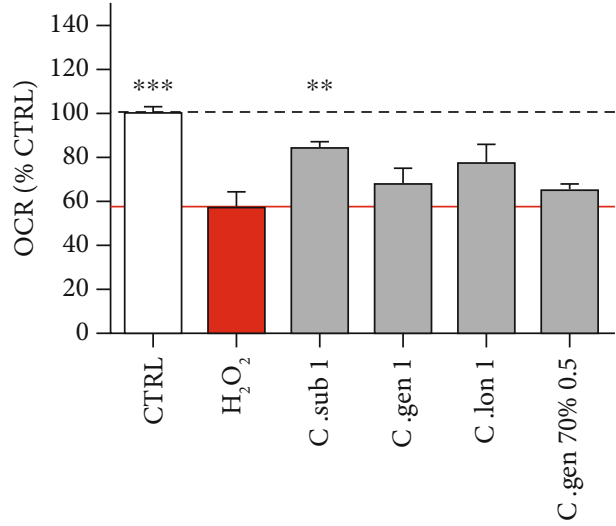

(a)

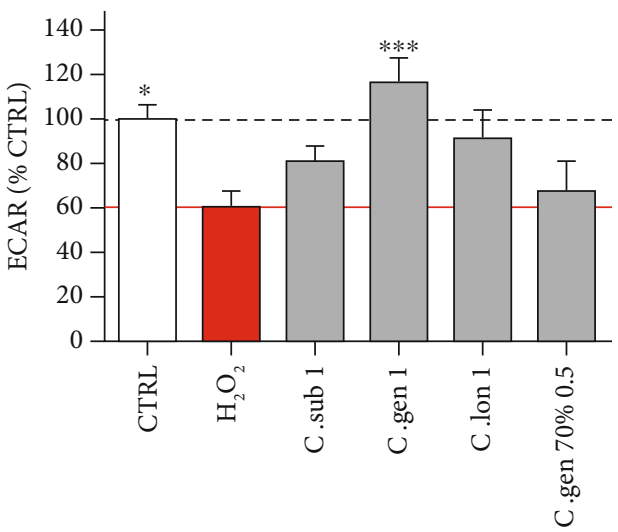

(b)

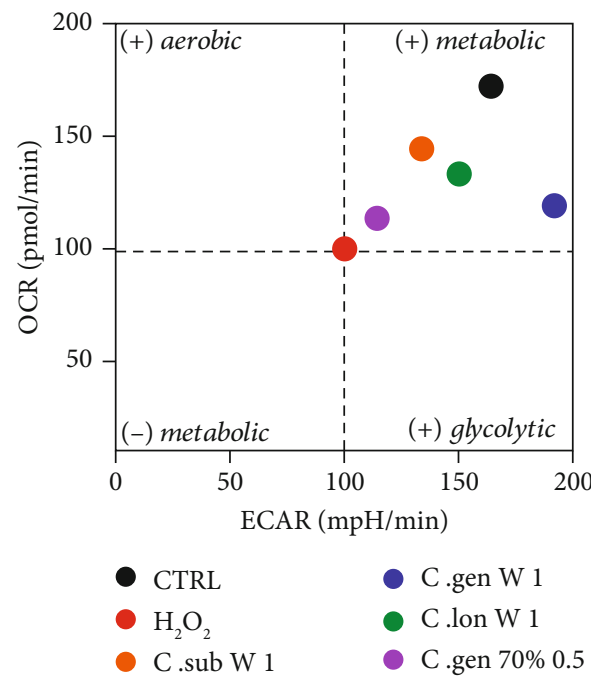

(c)

FIGURE 4: Respiration under oxidative stress condition. (a) $3 \mathrm{~h}$ treatment with $\mathrm{H}_{2} \mathrm{O}_{2}$ reduced the oxygen consumption rate by $41.7 \%$ (red bars). $24 \mathrm{~h}$ pretreatment with the water extract of C. subternata (at $1 \mathrm{ng} / \mathrm{ml}$ ) significantly ameliorated the oxygen consumption rate of the cells and therefore the respiration (grey bars). (b) $3 \mathrm{~h}$ treatment with $\mathrm{H}_{2} \mathrm{O}_{2}$ reduced the glycolysis by $38.9 \%$ (red bars). The aqueous extract of C. genistoides $(1 \mathrm{ng} / \mathrm{ml})$ significantly increased the glycolysis in SH-SY5Y cells. The red bar represents the $\mathrm{H}_{2} \mathrm{O}_{2}$-treated cells, and the grey bars represent cells that were pretreated for $24 \mathrm{~h}$ with the indicated honeybush extract and then treated for $3 \mathrm{~h}$ with $\mathrm{H}_{2} \mathrm{O}_{2}$. (c) Energy map created after correlation of the OCR (respiration- $y$-axis) with the ECAR (glycolysis- $x$-axis). This map helps in visually recognizing whether an extract predominantly increased the respiration (displayed as + metabolic in the figure) or the glycolytic activity compared to the $\mathrm{H}_{2} \mathrm{O}_{2}$-treated cells. Values represent as the mean $\pm \mathrm{SEM}$ of three independent experiments and were normalized on the untreated group $(=100 \%)$. One-way ANOVA and post hoc Dunnett's multiple comparison test versus $\mathrm{H}_{2} \mathrm{O}_{2}$-treated cells. ${ }^{*} P<0.05 ;{ }^{* *} P<0.01 ;{ }^{* * *} P<0.001$.

significant effect on the specific mitochondrial ROS. All extracts had thus a minimizing effect on ROS levels, though at different degrees and on different ROS types (Figure 6). This might be explained by different bioactive components in the specific extract depending on Cyclopia species and extraction solvent. While all the water extracts (C. subternata, C. genistoides, C. longifolia) act on mitochondrial superoxide anion levels, the ethanolic extract of $C$. genistoides only affects the cytosolic ROS and total superoxide anion levels. It is assumed that the latter extract acted specifically on cytosolic superoxide anions.

The most beneficial concentrations of the honeybush extracts in this study were found to be as low as 0.1 and $1 \mathrm{ng} / \mathrm{ml}$. Plant extracts are complex mixtures of a multitude of compounds of diverse chemistries and pharmacological activities at different concentrations. The different constituents in the plant extracts could have antagonistic, synergistic, or allosteric effects [37]. For example, an active substance at the higher concentration could have blunted the activity of another bioactive constituent. Possibly, there is one or several constituents that are effective at a low concentration and a gradual increase in concentrations may gradually reduce the efficacy and might explain the observed effect at very low concentrations.

Considering the phenolic profiles of the different extracts, it is clear that no pattern emerged that could explain differential activity. The total polyphenol content often highly correlates with the antioxidant activity in vitro but was similar in 


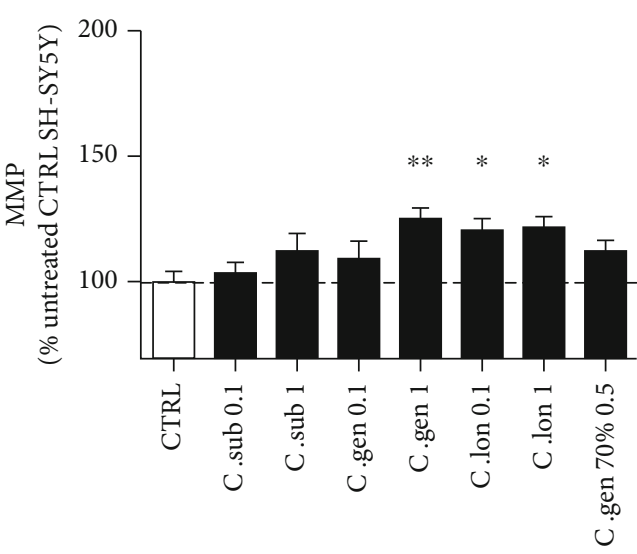

(a)

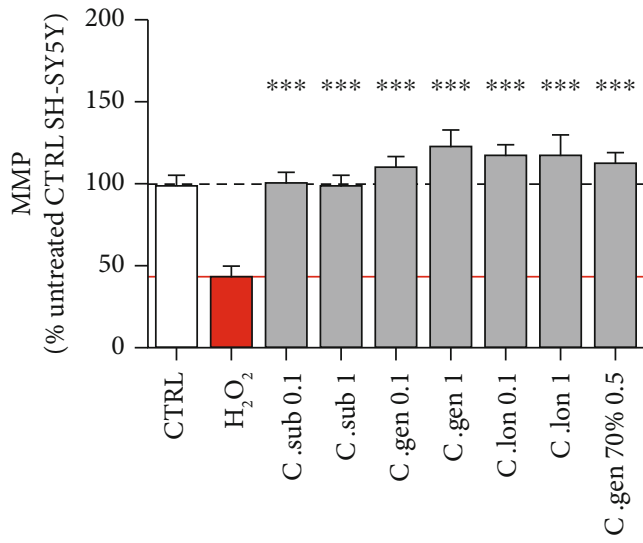

(b)

Figure 5: (a) Honeybush extracts significantly increased the mitochondrial membrane potential (MMP) up to 24\% under physiological conditions (black bars). (b) $3 \mathrm{~h}$ treatments with $\mathrm{H}_{2} \mathrm{O}_{2}$ at $400 \mu \mathrm{M}$ caused a reduction of 55.1\% in MMP which was rescued by the different honeybush extracts. The red bar represents the $\mathrm{H}_{2} \mathrm{O}_{2}$-treated cells, and the grey bars represent cells that were pretreated for $24 \mathrm{~h}$ with the indicated honeybush extract and then treated for $3 \mathrm{~h}$ with $\mathrm{H}_{2} \mathrm{O}_{2}$. Values represent as the mean \pm SEM of three independent experiments and were normalized on the untreated group $(=100 \%)$. One-way ANOVA and post hoc Dunnett's multiple comparison test versus (a) untreated (CTRL) or (b) $\mathrm{H}_{2} \mathrm{O}_{2} .{ }^{*} P<0.05 ;{ }^{* *} P<0.01 ;{ }^{* * *} P<0.001$.

the aqueous extracts of $C$. subternata, C. genistoides, and $C$. longifolia $(\sim 26,25$, and $24 \mathrm{~g}$ gallic acid equivalents per $100 \mathrm{~g}$ extract, respectively). In the ethanolic extract of $C$. genistoides, the phenolic content was slightly increased ( $\sim 28 \mathrm{~g}$ gallic acid equivalents per $100 \mathrm{~g}$ extract). However, the phenolic content does not differ substantially between the different extracts to provide an explanation to our findings. In fact, mangiferin, shown to have beneficial effects in in vitro and in vivo models of neurodegeneration, as well as of oxidative stress [38-43], was lowest in the C. subternata water extract and highest in the $70 \%$ ethanolic extract of C. genistoides. According to these studies, we expected that the $C$. genistoides $70 \%$ ethanolic extract would exert the most potent neuroprotective properties, while the aqueous extract of $C$. subternata would exert the least. Interestingly, the results of our experiments proved our assumption wrong as the opposite effect was observed with the aqueous extract of $C$. subternata being the most beneficial extract. A closer observation at the composition of the extracts (Table 1) reveals that the aqueous extract of $C$. subternata contains higher concentrations of flavones and dihydrochalcones. Scolymoside, present in the highest concentration in the C. subternata water extract and absent in detectable quantities in the two C. genistoides extracts, is a glycoside of luteolin, a flavone aglycone demonstrated to inhibit the production of neuronal mitochondrial superoxide anion $\mathrm{O}_{2}^{--}$[44]. While glycosylation of position C-7 of the A-ring of the flavonoid structure as for scolymoside would decrease its radical scavenging potency compared to luteolin, it does not abolish the activity [45]. Dihydrochalcones related to those in C. subternata not only act as radical scavengers [46] but also demonstrated neuroprotective effects $[47,48]$. The flavanone, hesperidin, present in the highest level in the $70 \%$ ethanolic extract of C. genistoides could alleviate oxidative stress [49] and act as neuroprotective agent, amongst others by enhancing endogenous antioxidant defense functions [50].
Regarding the bioavailability of the plant extract, it depends on the bioavailability of the single compounds contained in each extract. Extracts from different honeybush species vary in chemical composition. However, the main active constituents of honeybush have been reported to be mangiferin and hesperidin and there are some data available with regard to their bioavailability and their ability to cross the blood-brain barrier (BBB). Of note, trace amounts of mangiferin were found in the rat brain after an acute oral treatment with a single dose of a plant extract containing mangiferin indicating that the compound can cross the BBB [51], whereas in another study, mangiferin was not detected in the brain of rats after a single dose via intraperitoneal administration [52]. However, one has to take into consideration that different assays of different sensitivities were used in the two studies. In the study from Li et al. (2008), a validated highly sensitive HPLC method was developed and applied to detect mangiferin after a single oral dose of Rhizoma Anemarrhenae extract, while in the study of Zajac et al. (2012), a much less sensitive detection method (a simple TLC method) was used. Similarly, the bioavailability of the therapeutically active constituents of Ginkgo biloba extract (GBE) in the brain was formerly questioned until recent studies demonstrated the distribution of GBE in the brain of rats after single and repeated oral administration of GBE $[53,54]$. The compounds in this case were also successfully detected with an HPLC method. Hesperidin or its aglycone hesperetin seems to be able to traverse the $\mathrm{BBB}$ and directly exerts their neuroprotective effect in the brain [55-57].

Furthermore, bioavailability in the brain might be affected by the route of administration and by whether the pure compound is administered or contained in a plant extract but we can assume that mangiferin and hesperidin exert neuroprotective effects on the brain and peripheral neurons. 


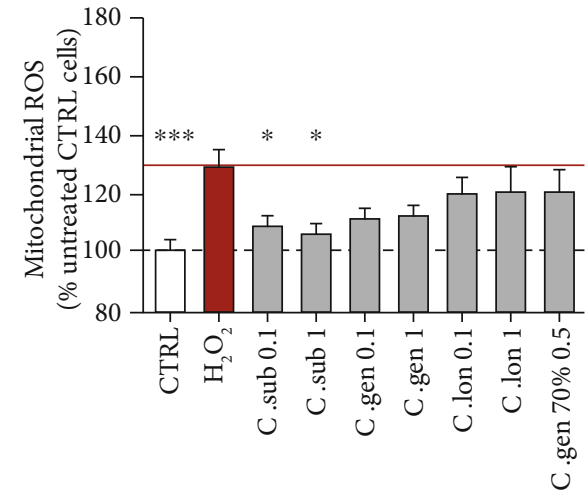

(a)

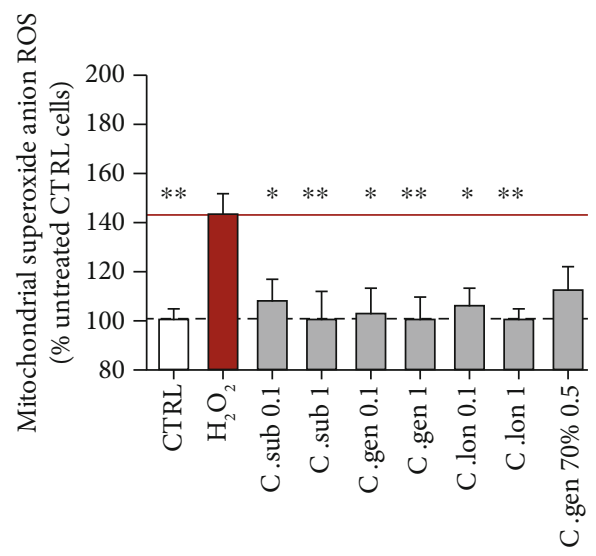

(c)

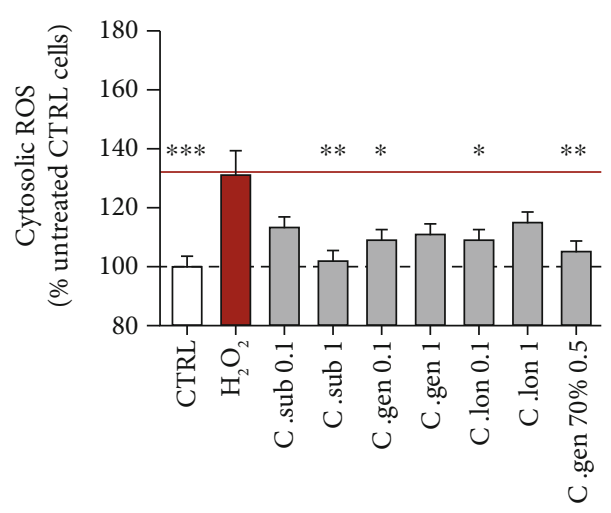

(b)

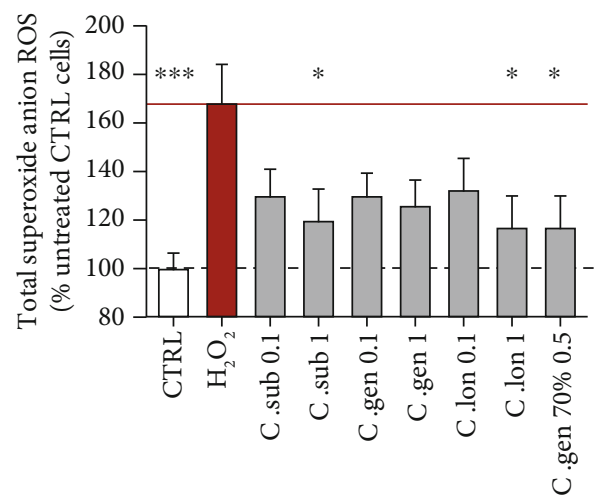

(d)

FiguRE 6: Effect of honeybush extracts on ROS levels under $\mathrm{H}_{2} \mathrm{O}_{2}$-induced oxidative stress. (a) $\mathrm{H}_{2} \mathrm{O}_{2}$ treatment at $400 \mu \mathrm{M}$ caused an increase of $29.5 \%$ in mitochondrial ROS which were detected using the dye DHR. This increase was significantly ameliorated up to $23.1 \%$ by $C$. subternata aqueous extract. (b) $\mathrm{H}_{2} \mathrm{O}_{2}$ caused an elevation of $31.2 \%$ in cytosolic ROS (detected with the dye DCF). All the extracts could bring the cytosolic ROS levels down, but the ones that reduced them significantly and most effectively were the aqueous extract of $C$. subternata at $1 \mathrm{ng} / \mathrm{ml}$ and the $70 \%$ ethanolic extract of C. genistoides at $0.5 \mathrm{ng} / \mathrm{ml}$. (c) $\mathrm{H}_{2} \mathrm{O}_{2}$ increased the mitochondrial superoxide anion levels by $43 \%$. All the extracts, except the ethanolic extract of $C$. genistoides, significantly reduced the mitochondrial superoxide anion levels. The aqueous extracts of C. subternata, C. genistoides, and C. longifolia at the concentration of $1 \mathrm{ng} / \mathrm{ml}$ each completely neutralized the mitochondrial superoxide anion levels. (d) The total superoxide anion levels were elevated by $67.9 \%$ in the $\mathrm{H}_{2} \mathrm{O}_{2}$-treated cells. All 4 extracts could ameliorate this increase but only the aqueous extracts of C. subternata at $1 \mathrm{ng} / \mathrm{ml}$, C. longifolia at $1 \mathrm{ng} / \mathrm{ml}$, and the ethanolic extract of C. genistoides at $0.5 \mathrm{ng} / \mathrm{ml}$ significantly reduced the superoxide anion levels. The red bar represents the $\mathrm{H}_{2} \mathrm{O}_{2}$-treated cells, and the grey bars represent cells that were pretreated for $24 \mathrm{~h}$ with the indicated honeybush extract and then treated for $3 \mathrm{~h}$ with $\mathrm{H}_{2} \mathrm{O}_{2}$. Values represent as the mean \pm SEM of three independent experiments and were normalized on the untreated group (=100\%). One-way ANOVA and post hoc Dunnett's multiple comparison test versus (a) untreated (CTRL) or (b) $\mathrm{H}_{2} \mathrm{O}_{2} \cdot{ }^{*} P<0.05 ;{ }^{* *} P<0.01 ;{ }^{* * *} P<0.001$.

To sum up, the results obtained from this study indicate that C. subternata aqueous extract is the most effective in enhancing mitochondrial functions especially under oxidative stress situations. It was the only one to act on respiration under oxidative stress and the only one to lower all four types of ROS measured in this study. These findings are particularly relevant for the establishment of honeybush tea as nutraceutical as the species that is mostly cultivated for the production of the tea is currently C. subternata. The other two aqueous extracts (C. genistoides and C. longifolia) also exert a beneficial effect. C. genistoides acted more on respiration under physiological conditions, while C. longifolia was more effective in neutralizing ROS (active against three types of ROS). Interestingly, in the tea industry, honeybush tea is often prepared after blending of different species. Therefore, evaluating the activity of a mixture of different species extracts will be very interesting.

\section{Conclusion}

In this study, the effects of honeybush extracts on enhancing mitochondrial and neuronal functions and on preventing the detrimental effects of oxidative stress were examined. The aqueous extract of $C$. subternata was superior to the other extracts in increasing mitochondrial functions and bioenergetics, especially under $\mathrm{H}_{2} \mathrm{O}_{2}$-induced oxidative stress. The aqueous extracts of $C$. genistoides and C. longifolia came next in terms of efficacy on mitochondrial functions. Lower extract concentrations $(0.1-1 \mathrm{ng} / \mathrm{ml})$ were also more effective. Overall, our data are in line with existing literature reporting 
an antioxidant effect of honeybush [19-22]. However, the effects of honeybush extracts on neuronal cells and specifically on mitochondrial function have been investigated here for the first time. Further research is ongoing by our team in order to study more in depth the effect of honeybush in combatting stress and in enhancing neuronal function. These findings make honeybush a potential candidate for prevention of oxidative stress, laying the foundation for further research aimed at the development of a condition-specific nutraceutical.

\section{Abbreviations}

\begin{tabular}{|c|c|}
\hline ADP: & Adenosine diphosphate \\
\hline ATP: & Adenosine triphosphate \\
\hline BBB: & Blood-brain barrier \\
\hline DCF: & $2^{\prime}, 7^{\prime}$-Dichlorodihydrofluorescein diacetate \\
\hline DHE: & Dihydroethidium \\
\hline DHR: & Dihydrorhodamine 123 \\
\hline DMEM: & Dulbecco's modified Eagle medium \\
\hline DMSO: & Dimethyl sulfoxide \\
\hline ECAR: & Extracellular acidification rate \\
\hline ESI: & Electrospray ionization \\
\hline ETC: & Electron transport chain \\
\hline $\mathrm{FADH}_{2}$ : & $\begin{array}{l}\text { Reduced form of flavin adenine dinucleotide } \\
\text { (FAD) }\end{array}$ \\
\hline FCCP: & $\begin{array}{l}\text { Carbonyl cyanide-4- } \\
\text { (trifluoromethoxy)phenylhydrazone }\end{array}$ \\
\hline FCS: & Fetal calf serum \\
\hline GBE: & Ginkgo biloba extract \\
\hline GSH: & Glutathione $(\gamma$-glutamylcysteinylglycine $)$ \\
\hline GSH: GSSG: & $\begin{array}{l}\text { Reduced glutathione to oxidised glutathione } \\
\text { ratio }\end{array}$ \\
\hline HBSS: & Hanks' balanced salt solution \\
\hline HPLC-DAD: & $\begin{array}{l}\text { High-performance liquid chromatography } \\
\text { with diode array detector }\end{array}$ \\
\hline IMM: & Inner mitochondrial membrane \\
\hline LC-MS: & Liquid chromatography-mass spectrometry \\
\hline MMP: & Mitochondrial membrane potential \\
\hline MS/MS: & Tandem mass spectrometry \\
\hline MtDNA: & Mitochondrial DNA \\
\hline NADH: & $\begin{array}{l}\text { Reduced form of nicotinamide adenine } \\
\text { dinucleotide }\end{array}$ \\
\hline OCR: & Oxygen consumption rate \\
\hline OXPHOS: & Oxidative phosphorylation \\
\hline PBS: & Phosphate-buffered saline \\
\hline Q-TOF: & Synapt G2 quadrupole time-of-flight \\
\hline ROS: & Reactive oxygen species \\
\hline SEM: & Standard error of the mean \\
\hline SH-SY5Y: & Human neuroblastoma cell line \\
\hline TMRM: & Tetramethylrhodamine methyl ester \\
\hline UPLC: & Ultra-performance liquid chromatography \\
\hline UV-Vis: & Ultraviolet-visibl \\
\hline
\end{tabular}

\section{Data Availability}

The data used to support the findings of this study are available from the corresponding author upon request.

\section{Conflicts of Interest}

The authors declare no conflict of interest.

\section{Acknowledgments}

This study was supported by a bilateral grant from the Swiss National Science Foundation (grant no. IZLSZ3_170858 to GIAE) and the NRF of South Africa (grant no. 107805 to EJ) between Switzerland and South Africa.

\section{References}

[1] A. Grimm, A. G. Mensah-Nyagan, and A. Eckert, "Alzheimer, mitochondria and gender," Neuroscience and Biobehavioral Reviews, vol. 67, pp. 89-101, 2016.

[2] A. Grimm and A. Eckert, "Brain aging and neurodegeneration: from a mitochondrial point of view," Journal of Neurochemistry, vol. 143, no. 4, pp. 418-431, 2017.

[3] I. Lejri, A. Agapouda, A. Grimm, and A. Eckert, "Mitochondria- and Oxidative Stress-Targeting Substances in Cognitive Decline- Related Disorders: From Molecular Mechanisms to Clinical Evidence," Oxidative Medicine and Cellular Longevity, vol. 2019, Article ID 9695412, 26 pages, 2019.

[4] N. Nissanka and C. T. Moraes, "Mitochondrial DNA damage and reactive oxygen species in neurodegenerative disease," FEBS Letters, vol. 592, no. 5, pp. 728-742, 2018.

[5] N. Kuksal, J. Chalker, and R. J. Mailloux, "Progress in understanding the molecular oxygen paradox - function of mitochondrial reactive oxygen species in cell signaling," Biological Chemistry, vol. 398, no. 11, pp. 1209-1227, 2017.

[6] W. E. Müller, A. Eckert, G. P. Eckert et al., "Therapeutic efficacy of the Ginkgo special extract EGb761 ${ }^{\circledR}$ within the framework of the mitochondrial cascade hypothesis of Alzheimer's disease," The World Journal of Biological Psychiatry, vol. 20, no. 3, pp. 173-189, 2017.

[7] J. Dan Dunn, L. A. J. Alvarez, X. Zhang, and T. Soldati, "Reactive oxygen species and mitochondria: a nexus of cellular homeostasis," Redox Biology, vol. 6, pp. 472-485, 2015.

[8] D. B. Zorov, M. Juhaszova, and S. J. Sollott, "Mitochondrial ROS-induced ROS release: an update and review," Biochimica et Biophysica Acta, vol. 1757, no. 5-6, pp. 509-517, 2006.

[9] D. Q. Tan and T. Suda, "Reactive oxygen species and mitochondrial homeostasis as regulators of stem cell fate and function," Antioxidants \& Redox Signaling, vol. 29, no. 2, pp. 149$168,2018$.

[10] A. Grimm, K. Friedland, and A. Eckert, "Mitochondrial dysfunction: the missing link between aging and sporadic Alzheimer's disease," Biogerontology, vol. 17, no. 2, pp. 281-296, 2016.

[11] X. Ren, L. Zou, X. Zhang et al., "Redox signaling mediated by thioredoxin and glutathione systems in the central nervous system," Antioxidants \& Redox Signaling, vol. 27, no. 13, pp. 989-1010, 2017.

[12] E. B. Kurutas, "The importance of antioxidants which play the role in cellular response against oxidative/nitrosative stress: current state," Nutrition Journal, vol. 15, no. 1, p. 71, 2016.

[13] P. Mecocci, V. Boccardi, R. Cecchetti et al., "A long journey into aging, brain aging, and Alzheimer's disease following the oxidative stress tracks," Journal of Alzheimer's Disease, vol. 62 , no. 3, pp. 1319-1335, 2018. 
[14] C. Giorgi, S. Marchi, I. C. M. Simoes et al., "Mitochondria and reactive oxygen species in aging and age-related diseases," International Review of Cell and Molecular Biology, vol. 340, pp. 209-344, 2018.

[15] I. Lejri, A. Grimm, and A. Eckert, "Mitochondria, estrogen and female brain aging," Frontiers in Aging Neuroscience, vol. 10, p. 124, 2018.

[16] E. Joubert, M. E. Joubert, C. Bester, D. de Beer, and J. H. de Lange, "Honeybush (Cyclopia spp.): from local cottage industry to global markets - the catalytic and supporting role of research," South African Journal of Botany, vol. 77, no. 4, pp. 887-907, 2011.

[17] E. Joubert, W. C. A. Gelderblom, A. Louw, and D. de Beer, "South African herbal teas: Aspalathus linearis, Cyclopia spp. and Athrixia phylicoides-a review," Journal of Ethnopharmacology, vol. 119, no. 3, pp. 376-412, 2008.

[18] D. L. McKay and J. B. Blumberg, "A review of the bioactivity of South African herbal teas: rooibos (Aspalathus linearis) and honeybush (Cyclopia intermedia)," Phytotherapy Research, vol. 21, no. 1, pp. 1-16, 2007.

[19] P. Dube, S. Meyer, and J. L. Marnewick, "Antimicrobial and antioxidant activities of different solvent extracts from fermented and green honeybush (Cyclopia intermedia) plant material," South African Journal of Botany, vol. 110, pp. 184-193, 2017.

[20] A. O. Lawal, L. M. Davids, and J. L. Marnewick, "Rooibos (Aspalathus linearis) and honeybush (Cyclopia species) modulate the oxidative stress associated injury of diesel exhaust particles in human umbilical vein endothelial cells," Phytomedicine, vol. 59, p. 152898, 2019.

[21] J. D. van der Merwe, D. de Beer, S. Swanevelder, E. Joubert, and W. C. A. Gelderblom, "Dietary exposure to honeybush (Cyclopia) polyphenol-enriched extracts altered redox status and expression of oxidative stress and antioxidant defenserelated genes in rat liver," South African Journal of Botany, vol. 110, pp. 230-239, 2017.

[22] J. L. Marnewick, E. Joubert, P. Swart, F. van der Westhuizen, and W. C. Gelderblom, "Modulation of hepatic drug metabolizing enzymes and oxidative status by rooibos (Aspalathus linearis) and Honeybush (Cyclopia intermedia), green and black (Camellia sinensis) teas in rats," Journal of Agricultural and Food Chemistry, vol. 51, no. 27, pp. 8113-8119, 2003.

[23] D. de Beer, A. Schulze, E. Joubert, A. de Villiers, C. Malherbe, and M. Stander, "Food ingredient extracts of Cyclopia subternata (Honeybush): variation in phenolic composition and antioxidant capacity," Molecules, vol. 17, no. 12, pp. 1460214624, 2012.

[24] A. E. Schulze, T. Beelders, I. S. Koch, L. M. Erasmus, D. de Beer, and E. Joubert, "Honeybush herbal teas (Cyclopia spp.) contribute to high levels of dietary exposure to xanthones, benzophenones, dihydrochalcones and other bioactive phenolics," Journal of Food Composition and Analysis, vol. 44, pp. 139-148, 2015.

[25] T. Beelders, D. de Beer, M. Stander, and E. Joubert, "Comprehensive phenolic profiling of Cyclopia genistoides (L.) Vent. by LC-DAD-MS and -MS/MS reveals novel xanthone and benzophenone constituents," Molecules, vol. 19, no. 8, pp. 1176011790, 2014.

[26] H. Arthur, E. Joubert, D. de Beer, C. J. Malherbe, and R. C. Witthuhn, "Phenylethanoid glycosides as major antioxidants in Lippia multiflora herbal infusion and their stability during steam pasteurisation of plant material," Food Chemistry, vol. 127, no. 2, pp. 581-588, 2011.
[27] A. Grimm, K. Schmitt, U. E. Lang, A. G. Mensah-Nyagan, and A. Eckert, "Improvement of neuronal bioenergetics by neurosteroids: Implications for age- related neurodegenerative disorders," Biochim Biophys Acta, vol. 1842, no. 12, pp. $2427-$ 2438, 2014.

[28] A. Grimm, E. E. Biliouris, U. E. Lang, J. Götz, A. G. MensahNyagan, and A. Eckert, "Sex hormone-related neurosteroids differentially rescue bioenergetic deficits induced by amyloid$\beta$ or hyperphosphorylated tau protein," Cellular and Molecular Life Sciences, vol. 73, no. 1, pp. 201-215, 2016.

[29] I. Lejri, A. Grimm, M. Miesch, P. Geoffroy, A. Eckert, and A. G. Mensah-Nyagan, "Allopregnanolone and its analog BR 297 rescue neuronal cells from oxidative stress-induced death through bioenergetic improvement," Biochimica et Biophysica Acta-Molecular Basis of Disease, vol. 1863, no. 3, pp. 631-642, 2017.

[30] K. Schmitt, A. Grimm, R. Dallmann et al., "Circadian control of DRP1 activity regulates mitochondrial dynamics and bioenergetics," Cell Metabolism, vol. 27, no. 3, pp. 657-666.e5, 2018, e5.

[31] A. Grimm, I. Lejri, F. Hallé et al., "Mitochondria modulatory effects of new TSPO ligands in a cellular model of tauopathies," Journal of Neuroendocrinology, vol. 32, no. 1, article e12796, 2020.

[32] Y. Poirier, A. Grimm, K. Schmitt, and A. Eckert, "Link between the unfolded protein response and dysregulation of mitochondrial bioenergetics in Alzheimer's disease," Cellular and Molecular Life Sciences, vol. 76, no. 7, pp. 1419-1431, 2019.

[33] A. Grimm, K. Schmitt, and A. Eckert, "Advanced mitochondrial respiration assay for evaluation of mitochondrial dysfunction in Alzheimer's disease," Methods in Molecular Biology, vol. 1303, pp. 171-183, 2016.

[34] K. Schmitt, A. Grimm, and A. Eckert, "Amyloid- $\beta$-Induced changes in molecular clock properties and cellular bioenergetics," Frontiers in Neuroscience, vol. 11, p. 124, 2017.

[35] S. Papa, P. L. Martino, G. Capitanio et al., "The oxidative phosphorylation system in mammalian mitochondria," Advances in Experimental Medicine and Biology, vol. 942, pp. 3-37, 2012.

[36] P. Dimroth, G. Kaim, and U. Matthey, "Crucial role of the membrane potential for ATP synthesis by $\mathrm{F}(1) \mathrm{F}(\mathrm{o})$ ATP synthases," The Journal of Experimental Biology, vol. 203, Part 1, pp. 51-59, 2000.

[37] L. K. Caesar and N. B. Cech, "Synergy and antagonism in natural product extracts: when $1+1$ does not equal 2," Natural Product Reports, vol. 36, no. 6, pp. 869-888, 2019.

[38] Z. Wang, S. Guo, J. Wang, Y. Shen, J. Zhang, and Q. Wu, "Nrf2/HO-1 mediates the neuroprotective effect of mangiferin on early brain injury after subarachnoid hemorrhage by attenuating mitochondria-related apoptosis and neuroinflammation," Scientific Reports, vol. 7, no. 1, p. 11883, 2017.

[39] S. Siswanto, W. Arozal, V. Juniantito, A. Grace, F. D. Agustini, and Nafrialdi, "The effect of mangiferin against brain damage caused by oxidative stress and inflammation induced by doxorubicin," HAYATI Journal of Biosciences, vol. 23, no. 2, pp. 51$55,2016$.

[40] S. Das, B. Nageshwar Rao, and B. S. Satish Rao, "Mangiferin attenuates methylmercury induced cytotoxicity against IMR32, human neuroblastoma cells by the inhibition of oxidative stress and free radical scavenging potential," Chemico-Biological Interactions, vol. 193, no. 2, pp. 129-140, 2011. 
[41] C. Infante-Garcia, J. J. Ramos-Rodriguez, I. Delgado-Olmos et al., "Long-term mangiferin extract treatment improves central pathology and cognitive deficits in APP/PS1 mice," Molecular Neurobiology, vol. 54, no. 6, pp. 4696-4704, 2017.

[42] M. Kavitha, J. Nataraj, M. M. Essa, M. A. Memon, and T. Manivasagam, "Mangiferin attenuates MPTP induced dopaminergic neurodegeneration and improves motor impairment, redox balance and Bcl-2/Bax expression in experimental Parkinson's disease mice," Chemico-Biological Interactions, vol. 206, no. 2, pp. 239-247, 2013.

[43] S. T. Feng, Z. Z. Wang, Y. H. Yuan, H. M. Sun, N. H. Chen, and Y. Zhang, "Mangiferin: a multipotent natural product preventing neurodegeneration in Alzheimer's and Parkinson's disease models," Pharmacological Research, vol. 146, p. 104336, 2019.

[44] Y. Y. Tan, J. Xu, P. Zhang et al., "Luteolin exerts neuroprotection via modulation of the $\mathrm{p} 62 / \mathrm{Keap} 1 / \mathrm{Nrf2}$ pathway in intracerebral hemorrhage," Frontiers in Pharmacology, vol. 10, p. 1551, 2020.

[45] O. Farkas, J. Jakus, and K. Heberger, "Quantitative structureantioxidant activity relationships of flavonoid compounds," Molecules, vol. 9, no. 12, pp. 1079-1088, 2004.

[46] X. Li, B. Chen, H. Xie, Y. He, D. Zhong, and D. Chen, “Antioxidant structure(-)activity relationship analysis of five dihydrochalcones," Molecules, vol. 23, no. 5, p. 1162, 2018.

[47] D. Barreca, M. Currò, E. Bellocco et al., "Neuroprotective effects of phloretin and its glycosylated derivative on rotenone-induced toxicity in human SH-SY5Y neuronal-like cells," BioFactors, vol. 43, no. 4, pp. 549-557, 2017.

[48] Y. Liu, L. Zhang, and J. Liang, "Activation of the Nrf2 defense pathway contributes to neuroprotective effects of phloretin on oxidative stress injury after cerebral ischemia/reperfusion in rats," Journal of the Neurological Sciences, vol. 351, no. 1-2, pp. 88-92, 2015.

[49] D. Wang, L. Liu, X. Zhu, W. Wu, and Y. Wang, "Hesperidin alleviates cognitive impairment, mitochondrial dysfunction and oxidative stress in a mouse model of Alzheimer's disease," Cellular and Molecular Neurobiology, vol. 34, no. 8, pp. 12091221, 2014.

[50] M. Hajialyani, M. Hosein Farzaei, J. Echeverría, S. Nabavi, E. Uriarte, and E. Sobarzo-Sánchez, "Hesperidin as a neuroprotective agent: a review of animal and clinical evidence," Molecules, vol. 24, no. 3, p. 648, 2019.

[51] Y.-J. Li, Y. J. Sui, Y. H. Dai, and Y. L. Deng, "LC determination and pharmacokinetics study of mangiferin in rat plasma and tissues," Chromatographia, vol. 67, no. 11-12, pp. 957-960, 2008.

[52] D. Zajac, A. Stasinska, R. Delgado, and M. Pokorski, "Mangiferin and its traversal into the brain," Advances in Experimental Medicine and Biology, vol. 756, pp. 105-111, 2013.

[53] L. Rangel-Ordóñez, M. Nöldner, M. Schubert-Zsilavecz, and M. Wurglics, "Plasma levels and distribution of flavonoids in rat brain after single and repeated doses of StandardizedGinkgo bilobaExtract EGb 761 ${ }^{\circledR}$," Planta Medica, vol. 76, no. 15 , pp. 1683-1690, 2010.

[54] C. Ude, M. Schubert-Zsilavecz, and M. Wurglics, "Ginkgo biloba extracts: a review of the pharmacokinetics of the active ingredients," Clinical Pharmacokinetics, vol. 52, no. 9, pp. 727-749, 2013.

[55] K. A. Youdim, M. S. Dobbie, G. Kuhnle, A. R. Proteggente, N. J. Abbott, and C. Rice-Evans, "Interaction between flavo- noids and the blood-brain barrier: in vitro studies," Journal of Neurochemistry, vol. 85, no. 1, pp. 180-192, 2003.

[56] A. Roohbakhsh, H. Parhiz, F. Soltani, R. Rezaee, and M. Iranshahi, "Neuropharmacological properties and pharmacokinetics of the citrus flavonoids hesperidin and hesperetin-a mini-review," Life Sciences, vol. 113, no. 1-2, pp. 1-6, 2014.

[57] U. Z. Said, H. N. Saada, M. S. Abd-Alla, M. E. Elsayed, and A. M. Amin, "Hesperidin attenuates brain biochemical changes of irradiated rats," International Journal of Radiation Biology, vol. 88, no. 8, pp. 613-618, 2012. 